\title{
Increased microbial sequestration of soil organic carbon under nitrogen deposition over China's terrestrial ecosystems
}

\author{
Shu Liao', Siyi Tann ${ }^{1}$, Yan Peng ${ }^{2}$, Dingyi Wang ${ }^{1}$, Xiangyin $\mathrm{Ni}^{1}$, Kai Yue ${ }^{1,3}$, Fuzhong $\mathrm{Wu}^{1 *}$ (D) and Yusheng Yang ${ }^{1}$
}

\begin{abstract}
Background: China's terrestrial ecosystems have been receiving increasing amounts of reactive nitrogen $(\mathrm{N})$ over recent decades. External $\mathrm{N}$ inputs profoundly change microbially mediated soil carbon (C) dynamics, but how elevated $\mathrm{N}$ affects the soil organic $\mathrm{C}$ that is derived from microbial residues is not fully understood. Here, we evaluated the changes in soil microbial necromass $C$ under $\mathrm{N}$ addition at 11 forest, grassland, and cropland sites over China's terrestrial ecosystems through a meta-analysis based on available data from published articles.

Results: Microbial necromass C accounted for an average of $49.5 \%$ of the total soil organic $C$ across the studied sites, with higher values observed in croplands (53.0\%) and lower values in forests (38.6\%). Microbial necromass C was significantly increased by $9.5 \%$ after $\mathrm{N}$ addition, regardless of $\mathrm{N}$ forms, with greater stimulation observed for fungal $(+11.2 \%)$ than bacterial $(+4.5 \%)$ necromass $C$. This increase in microbial necromass $C$ under elevated $\mathrm{N}$ was greater under longer experimental periods but showed little variation among different $\mathrm{N}$ application rates. The stimulation of soil microbial necromass $\mathrm{C}$ under elevated $\mathrm{N}$ was proportional to the change in soil organic $\mathrm{C}$.

Conclusions: The stimulation of microbial residues after biomass turnover is an important pathway for the observed increase in soil organic C under N deposition across China's terrestrial ecosystems.
\end{abstract}

Keywords: Microbial necromass carbon, Nitrogen deposition, Amino sugars, Soil organic carbon

\section{Introduction}

Atmospheric nitrogen $(\mathrm{N})$ deposition, primarily originating from fossil fuel combustions and artificial fertilizer applications, has increased more than tenfold over the past century (Fowler et al. 2013) and has currently reached an average of $20.4 \mathrm{~kg} \mathrm{~N} / \mathrm{ha} / \mathrm{yr}$ over China's terrestrial ecosystems (Yu et al. 2019). Soils retain the largest pool of terrestrial organic carbon $(C)$, and the soil $C$ budget plays a prominent role in mitigating global change (Reay et al. 2008). Therefore, understanding the interactions between atmospheric $\mathrm{N}$ deposition and soil $\mathrm{C}$ sequestration is becoming increasingly important due to the consistent

\footnotetext{
* Correspondence: wufzchina@fjnu.edu.cn

'Key Laboratory for Humid Subtropical Eco-Geographical Processes of the Ministry of Education, School of Geographical Sciences, Fujian Normal University, 8 Shangshan Rd, Fuzhou 350007, Cangshan, China Full list of author information is available at the end of the article
}

increase in soil $\mathrm{N}$ availability under $\mathrm{N}$ deposition over China's terrestrial ecosystems (Liu et al. 2013).

Increasing evidence has indicated that atmospheric $\mathrm{N}$ deposition has the potential to increase soil organic $C$ storage by multiple pathways (Janssens et al. 2010; Liu and Greaver 2010). On the one hand, $\mathrm{N}$ is a limiting nutrient for plant growth in most terrestrial ecosystems, so $\mathrm{N}$ addition can profoundly facilitate plant growth and increase plant C input (LeBauer and Treseder 2008; Song et al. 2019). Moreover, elevated $\mathrm{N}$ increases plant lignin content (Liu et al. 2016), and high lignin content has been found to reduce litter decomposition under $\mathrm{N}$ addition (Knorr et al. 2005), increasing the amounts of litter materials on the soil surface without being decomposed (Zak et al. 2008). On the other hand, soil fungal peroxidase gene expression (Eisenlord et al. 2013; Zak et al. 2019) and associated lignin modifying enzymes
Springer Open (c) The Author(s). 2020 Open Access This article is licensed under a Creative Commons Attribution 4.0 International License, which permits use, sharing, adaptation, distribution and reproduction in any medium or format, as long as you give appropriate credit to the original author(s) and the source, provide a link to the Creative Commons licence, and indicate if changes were made. The images or other third party material in this article are included in the article's Creative Commons licence, unless indicated otherwise in a credit line to the material. If material is not included in the article's Creative Commons licence and your intended use is not permitted by statutory regulation or exceeds the permitted use, you will need to obtain permission directly from the copyright holder. To view a copy of this licence, visit http://creativecommons.org/licenses/by/4.0/. 
(Chen et al. 2018) have been found to be greatly reduced after $\mathrm{N}$ addition. A meta-analysis with data compilation from multiple studies also suggested that the soil lignin content was increased by an average of $7.3 \%$ under $\mathrm{N}$ addition, regardless of the $\mathrm{N}$ application rate and experimental duration (Liu et al. 2016), suggesting that the decline in the microbial decomposition of plant-derived soil organic $\mathrm{C}$ is a key process contributing to the increase in soil C storage under elevated $\mathrm{N}$ (Zak et al. 2008).

Recent studies found that microbial residues after biomass turnover account for approximately $30-62 \%$ of soil organic $C$ in the upper $30 \mathrm{~cm}$ of soil (Liang et al. 2019; $\mathrm{Ni}$ et al. 2020a), but how elevated $\mathrm{N}$ affects microbialderived soil organic $C$ is unclear. It is well known that soil microbial activity is highly sensitive to elevated $\mathrm{N}$ (Ramirez et al. 2012), with marked declines in microbial biomass and extracellular enzymes after $\mathrm{N}$ addition in a broad suite of ecosystems types (Jian et al. 2016; Liu and Greaver 2010). The microbial N mining hypothesis suggests that $\mathrm{N}$ input alleviates microbial $\mathrm{N}$ limitation; thus, soil microorganisms have lowered $\mathrm{N}$ requirements from recalcitrant compounds under external $\mathrm{N}$ input (Moorhead and Sinsabaugh 2006; Craine et al. 2007). Moreover, $\mathrm{N}$ addition reduces the abundance of oligotrophic microbes, which are adept at catabolizing more recalcitrant $\mathrm{C}$ compounds, as they may be outcompeted by copiotrophic taxa with higher $\mathrm{N}$ demands (Ramirez et al. 2012). The observed decrease in the fungal to bacterial ratio across a wide range of ecosystems (Zhang et al. 2018) confirmed these hypotheses and suggested that a shift in the microbial community composition towards the bacterial decomposition of soil organic $\mathrm{C}$ is another crucial mechanism explaining the increased soil $\mathrm{C}$ storage under $\mathrm{N}$ addition (Freedman et al. 2016; Wang et al. 2018; Liu et al. 2020).

However, the current synthesis does not distinguish the soil organic $\mathrm{C}$ that originates from microbial residues, and we do not know if soil microbial necromass $C$ responds in a similar way to microbial biomass $\mathrm{C}$ to $\mathrm{N}$ deposition. Moreover, most of our current understanding of stimulated soil $\mathrm{C}$ sequestration under $\mathrm{N}$ deposition is derived from the results of decreased decomposition of soil organic $\mathrm{C}$ under elevated $\mathrm{N}$ (Janssens et al. 2010; Liu and Greaver 2010); we still lack direct evidence of whether the accumulation of soil microbial necromass $C$ increases under elevated N. Benefiting from amino sugar biomarkers, we can quantify the microbial-derived $\mathrm{C}$ from the total soil organic $\mathrm{C}$ (Joergensen 2018; Liang et al. 2019). Bound amino sugars that can be hydrolyzed from microbial cell walls (such as fungal chitin and bacterial peptidoglycans and glycoproteins) have been extensively used as proxies for microbial residues in soils (Hu et al. 2020). Glucosamine primarily originates from fungal chitin, while muramic acid mainly exists in peptidoglycans in bacterial cell walls; these amino sugars are specific biomarkers for fungal and bacterial necromass $\mathrm{C}$, respectively (Joergensen 2018). To date, how elevated $\mathrm{N}$ affects soil microbial necromass $\mathrm{C}$ remains unclear; thus, a comprehensive picture that incorporates microbial necromass $\mathrm{C}$ would provide new insights into the sophisticated mechanisms that govern soil organic $\mathrm{C}$ in response to $\mathrm{N}$ deposition.

Here, we assessed the changes in soil microbial necromass $\mathrm{C}$ after $\mathrm{N}$ addition at 11 forest, grassland, and cropland sites across China's terrestrial ecosystems through a meta-analysis based on available data from published articles. We hypothesize that elevated $\mathrm{N}$ increases soil microbial necromass $\mathrm{C}$ accumulation, and changes in microbial necromass $\mathrm{C}$ are proportional to changes in microbial biomass $\mathrm{C}$ after $\mathrm{N}$ addition. Our objectives of this study are to quantify the proportion of microbial residues in soil organic $\mathrm{C}$ and the change in microbial necromass $\mathrm{C}$ under $\mathrm{N}$ addition across China's terrestrial ecosystems.

\section{Materials and methods Data compilation}

The experiments to determine the concentrations of soil microbial necromass $\mathrm{C}$ or proxies (i.e., amino sugars) under $\mathrm{N}$ addition were screened by the Web of Science and China National Knowledge Infrastructure databases. The search terms were "nitrogen addition" OR "nitrogen deposition" OR "nitrogen enrichment" OR "nitrogen fertilization" AND "microbial/fungal/bacterial necromass" OR "microbial/fungal/bacterial residues" OR "amino sugars" OR "glucosamine" OR "muramic acid." All literature data were retrieved from peer-reviewed journal articles that were published before May 2020, with $\mathrm{N}$ addition experiments conducted in China.

Data compilation was performed based on the following criteria to reduce publication bias from different articles. First, the concentrations of fungal and bacterial necromass $\mathrm{C}$ that were calculated based on glucosamine and muramic acid were included in our dataset if the data could be retrieved from the articles directly. However, the majority of these data were presented as amino sugars without being converted to microbial necromass $\mathrm{C}$; in such cases, the concentrations of glucosamine and muramic acid were retrieved to calculate the concentrations of fungal and bacterial necromass $\mathrm{C}$ based on empirical conversion factors (see the "Data calculation for microbial necromass C" section). The calculated microbial necromass $\mathrm{C}$ was significantly correlated with amino sugars $(P<0.0001$; Fig. S1). Moreover, there was no significant difference in the concentrations of total microbial $(P=0.513)$, fungal $(P=0.711)$, and bacterial $(P=$ 0.390; Fig. S2) necromass $C$ between the dataset including only the directly obtained data and the dataset 
including both data sources (those obtained directly and calculated by amino sugars). Therefore, we pooled the data that were obtained directly from the articles and that were calculated by amino sugars in this study. A total of 16 articles reporting soil microbial necromass $\mathrm{C}$ or proxies under $\mathrm{N}$ addition at 11 forest, grassland, and cropland sites (Tables S1 and S2) were included.

Second, the concentration and volume of hydrochloric acid $(\mathrm{HCl})$ affect the release of amino sugars from soils (Zelles 1988), and the maximum release of amino sugars occurs after 6 or $8 \mathrm{~h}$ of $\mathrm{HCl}$ hydrolysis (Zhang and Amelung 1996). To yield reliable estimates of the microbial necromass $C$ that were calculated by amino sugars under $\mathrm{N}$ addition from different studies, we included only data from samples hydrolyzed by $6 \mathrm{~mol} / \mathrm{L} \mathrm{HCl}$ at $105^{\circ} \mathrm{C}$ for 6 or $8 \mathrm{~h}$. As all the included studies followed the gas or liquid chromatography method with similar procedures for the separation of amino sugars (Table S3), we ignored the methodological difference for determining the concentrations of soil amino sugars between studies.

Third, previous studies have found that the concentrations of both soil organic $\mathrm{C}$ ( $\mathrm{Li}$ et al. 2019) and amino sugars (Ni et al. 2020b) significantly varied at different depths. To allow valid comparisons to assess the influence of $\mathrm{N}$ addition on soil microbial necromass $\mathrm{C}$ from different studies, only the data from samples that were collected in the upper 20 -cm layer of soils were included in our dataset.

Fourth, the data collected under different $\mathrm{N}$ doses and experimental periods were included in our dataset to assess the magnitudes and durations of $\mathrm{N}$ addition effects on soil microbial necromass $C$. However, when the same results were presented in different publications by the same research group, these data were only included once. The $\mathrm{N}$ doses presented as $\mathrm{g} \mathrm{N} / \mathrm{kg}$ soil in laboratory incubations were calculated as $\mathrm{kg} \mathrm{N} / \mathrm{ha} / \mathrm{yr}$ according to the soil bulk density, sampling depths, and experimental durations.

Fifth, to assess the correlations of microbial necromass $\mathrm{C}$ and soil geochemical variables, the latitude, elevation, mean annual temperature (MAT) and precipitation (MAP), soil bulk density, clay content, soil $\mathrm{pH}$, and $\mathrm{C}$ and $\mathrm{N}$ concentrations at the 11 sites were included in our dataset (Table S2). Missing elevation data were obtained by Google Earth (Google Inc., Santa Clara, CA, USA) according to the coordinates provided in the articles.

Sixth, the $\mathrm{N}$ addition and control plots were subjected to the same ambient conditions without other treatments, such as warming, carbon dioxide enrichment, or other global changes.

Seventh, the mean values, standard deviations, and sample sizes of both $\mathrm{N}$ addition and control plots were obtained directly from the articles to calculate the weighted effect sizes (see the "Response metrics" section). If only standard errors were presented in the articles, then they were converted to standard deviations based on the sample sizes. The results without standard deviations or standard errors were not included in our dataset.

Eighth, if the data were presented in figures, they were retrieved by Engauge Digitizer 4.1 (Free Software Foundation Inc., Boston, MA, USA). Data presented in supplementary materials accompanying an article were also included in our dataset. Additional detailed information on the data sources is presented in Supplementary Text S1 and Dataset S1.

A total of 118 paired observations that reported the concentrations of microbial necromass $\mathrm{C}$ under $\mathrm{N}$ addition were included in our dataset. The latitude ranged from $18.74{ }^{\circ} \mathrm{N}$ to $47.43{ }^{\circ} \mathrm{N}$, elevation from 36 to $3220 \mathrm{~m}$, MAT from -1.2 to $21.0^{\circ} \mathrm{C}$, and MAP from 460 to $2200 \mathrm{~mm}$.

\section{Data calculation for microbial necromass $C$}

The microbial necromass $\mathrm{C}$ data obtained directly or calculated by amino sugars were collected from forests, grasslands, and croplands under $\mathrm{N}$ addition. However, the influence of $\mathrm{N}$ addition on total microbial $(P=$ $0.659)$, fungal $(P=0.615)$, and bacterial $(P=0.557$; Fig. S3) necromass $C$ was not significant among ecosystems (Table S4). Therefore, we combined all data collected from forests, grasslands, and croplands and did not consider the differences among ecosystems.

Some studies reported only the concentrations of soil amino sugars and not microbial necromass $\mathrm{C}$ under $\mathrm{N}$ addition. Here, the fungal and bacterial necromass $\mathrm{C}$ were calculated from glucosamine and muramic acid, respectively, according to empirical conversion factors, as reviewed by Liang et al. (2019).

Specifically, muramic acid occurs only in bacterial cell walls and is a specific biomarker for bacterial necromass C (Eq. 1).

$$
\begin{aligned}
& \text { Bacterial necromass } \mathrm{C}(\mathrm{mg} / \mathrm{g} \text { soil }) \\
& =\text { Muramic acid }(\mathrm{mg} / \mathrm{g} \text { soil }) \times 45
\end{aligned}
$$

where 45 is the conversion factor from muramic acid to bacterial necromass $\mathrm{C}$.

Glucosamine occurs in both fungal and bacterial cell walls, so fungal necromass $C$ (Eq. 2) was calculated by subtracting the bacterial-derived glucosamine from the total glucosamine, assuming that muramic acid and glucosamine occur at a 1:2 molar ratio in bacterial cell walls. 
Fungal necromass $\mathrm{C}(\mathrm{mg} / \mathrm{g}$ soil $)=($ Glucosamine $(\mathrm{mg} / \mathrm{g}$ soil $) / 179.17-2$

$$
\times \text { Muramic acid }(\mathrm{mg} / \mathrm{g} \text { soil }) / 251.23) \times 179.17 \times 9
$$

where 9 is the conversion factor from glucosamine to fungal necromass $\mathrm{C}$, and 179.17 and 251.23 are the molecular weights of glucosamine and muramic acid, respectively (Liang et al. 2019).

The total microbial necromass $C$ is the sum of fungal and bacterial necromass $C$ and was calculated as the proportion of total soil organic $\mathrm{C}$ following our previous procedure (Ni et al. 2020a). The microbial necromass $\mathrm{C}$ to biomass $\mathrm{C}$ ratio (based on the chloroform fumigation extraction method) was calculated at sites where the microbial biomass $\mathrm{C}$ concentrations were determined. These values were calculated for the $\mathrm{N}$ addition and control plots separately and presented on the basis of both the soil dry mass (mg/g soil) and soil organic $\mathrm{C}$ concentration (\% C).

\section{Response metrics}

Weighted effect sizes were used to quantify the overall influence of $\mathrm{N}$ addition on soil microbial necromass $\mathrm{C}$ following our previous procedures (Ni et al. 2017). The mean values $\left(X_{\mathrm{N}}\right.$ for $\mathrm{N}$ addition and $X_{\mathrm{c}}$ for control), standard deviations ( $S_{\mathrm{N}}$ for $\mathrm{N}$ addition and $S_{\mathrm{c}}$ for control), and sample sizes ( $n_{\mathrm{N}}$ for $\mathrm{N}$ addition and $n_{\mathrm{c}}$ for control) at both the $\mathrm{N}$ addition and control plots were employed to calculate the individual effect size ( $\ln E$; Eq. 3; Tables $S 5$ and S6; Dataset S2), variance ( $v$; Eq. 4$)$, and weighting factor ( $w$; Eq. 5). The frequency of individual effect size was assumed to follow a normal distribution and to fit a Gaussian function (all $P<0.0001$; Fig. S4).

$$
\begin{aligned}
& \ln E=\ln \left(\frac{X_{\mathrm{N}}}{X_{\mathrm{c}}}\right) \\
& v=\frac{S_{\mathrm{N}}^{2}}{n_{\mathrm{N}} X_{\mathrm{N}}^{2}}+\frac{S_{\mathrm{c}}^{2}}{\mathrm{n}_{\mathrm{c}} X_{\mathrm{c}}^{2}} \\
& w=\frac{1}{v}
\end{aligned}
$$

Weighted effect size ( $\ln E E$; Eq. 6) and its 95\% bootstrap confidence intervals (CI; Eq. 8 based on Eq. 7) were calculated from individual $\ln E_{i}(i=1,2,3, \ldots, n)$ in a mixed model in MetaWin 2.0 (Rosenberg et al. 2000) as the average effect size by assigning a greater weight to the entry with lower variance to improve the precision of our analysis.

$$
\begin{gathered}
\ln E E=\frac{\sum_{i=1}^{n} w_{i} \ln E_{i}}{\sum_{i=1}^{n} w_{i}} \\
S_{\ln E E}=\sqrt{\frac{1}{\sum_{i=1}^{n} w_{i}}} \\
95 \% \text { CIs }=\ln E E \pm 1.96 \times S_{\ln E E}
\end{gathered}
$$

Here, $n$ is the number of entries for a variable and $i$ is the $i$ th entry. Given that the number of paired observations is limited in this study, a resampling test with 999 interactions was used to assess the $95 \%$ bootstrap CI. The influence of $\mathrm{N}$ addition on a variable is identified as positive if the weighted effect size is greater than zero; otherwise, it is designated as negative. The influence of $\mathrm{N}$ addition on a variable is considered significant if the 95\% bootstrap CI does not overlap with zero.

The percent change $(P C$; Eq. 9) of a variable in response to $\mathrm{N}$ addition was calculated based on the weighted effect size (Table S7).

$$
P C(\%)=\left(e^{\ln E E}-1\right) \times 100
$$

All variables for microbial necromass $C$, amino sugars, microbial biomass $\mathrm{C}$, and phospholipid fatty acids (PLFAs) and their variations at different $\mathrm{N}$ forms, doses, and durations were calculated as percent changes under $\mathrm{N}$ addition following the above procedures.

\section{Statistical analysis}

Weighted effect sizes and their 95\% bootstrap CIs were used to quantitatively assess the influence of $\mathrm{N}$ addition on all variables and their significant differences. Total and between-group heterogeneities $(Q)$ and their probabilities $(P)$ were calculated in MetaWin 2.0 to assess the total effect of $\mathrm{N}$ addition on variables (microbial necromass $\mathrm{C}$, microbial biomass $\mathrm{C}$, and PLFAs) and their variations among $\mathrm{N}$ doses, durations, and forms and between field and laboratory studies. A Bray-Curtis analysis was employed to compare the difference in soil microbial necromass $\mathrm{C}$ between the control and $\mathrm{N}$ addition plots. We also calculated the average concentrations of microbial necromass $\mathrm{C}$ and biomass $\mathrm{C}$ for the control and $\mathrm{N}$ addition plots, and a paired-samples $t$ test was used to compare these differences.

We used a stepwise regression in SPSS 20.0 (IBM SPSS, Chicago, IL, USA) to quantify the relative contributions of geographical (latitude and elevation), climatic (MAT and MAP), soil physical (bulk density and clay content), and chemical ( $\mathrm{pH}, \mathrm{C}$ and $\mathrm{N}$ concentrations 
and $\mathrm{C} / \mathrm{N}$ ratio) factors to total microbial, fungal, and bacterial necromass $\mathrm{C}$. We also used redundancy analysis (RDA) in Canoco 5 (ter Braak and Šmilauer 2012) to test the relationships between microbial necromass $\mathrm{C}$ and geochemical variables. These variables were collected at the control plots without $\mathrm{N}$ addition at which the microbial necromass $\mathrm{C}$ data were obtained.

\section{Results}

Average concentrations of soil microbial necromass $C$ and biomass $\mathrm{C}$ after $\mathrm{N}$ addition

The average concentrations of microbial necromass $C$ were 11.0 and $12.0 \mathrm{mg} / \mathrm{g}$ soil $(P<0.001$; Fig. $1 \mathrm{a})$, accounting for $57 \%$ and $62 \%$ of the soil organic $\mathrm{C}$ in the control and $\mathrm{N}$ addition plots, respectively $(P<0.001$; Fig. $1 \mathrm{~b})$. The absolute concentrations of microbial biomass $C$ were 0.29 and 0.38 $\mathrm{mg} / \mathrm{g}$ soil $(P=0.022$; Fig. $1 \mathrm{c})$ but only accounted for $2.7 \%$ and $2.6 \%$ of the soil organic $\mathrm{C}$ in the control and $\mathrm{N}$ addition plots, respectively $(P=0.58$; Fig. $1 \mathrm{~d})$. In addition, the average concentration of soil organic $C$ was higher $(P=0.018$; Fig. 1e) in the $\mathrm{N}$ addition plots. However, the microbial necromass $C$ to biomass $C$ ratio did not differ $(P=0.94$; Fig. 1f) between the control and $\mathrm{N}$ addition plots.

\section{Changes in soil microbial necromass $\mathrm{C}$ and biomass $\mathrm{C}$ after $\mathbf{N}$ addition}

The concentrations of total microbial, fungal, and bacterial PLFAs were increased by $25.7 \%, 32.2 \%$, and $17.4 \%$, respectively, after $\mathrm{N}$ addition (Fig. 2a). The concentration of total amino sugars was increased by $8.4 \%$, and the concentrations of glucosamine (biomarker for fungal residues) and muramic acid (biomarker for bacterial residues) were significantly increased by $11.2 \%$ and $4.5 \%$, respectively, after $\mathrm{N}$ addition (Fig. 2b). Similarly, the concentrations of total microbial, fungal, and bacterial necromass $\mathrm{C}$ significantly differed between control and $\mathrm{N}$ addition plots (all $P<0.05$; Fig. S5) and were significantly increased by $9.5 \%, 11.2 \%$, and $4.5 \%$, respectively, after $\mathrm{N}$ addition (Fig. 2c).

The soil organic $\mathrm{C}$ concentration was only increased by $3.6 \%$, although the concentration of microbial biomass $\mathrm{C}$ was dramatically stimulated by $50.4 \%$ after $\mathrm{N}$ addition at the studied sites (Fig. 3a). Changes in either microbial biomass $C\left(R^{2}=0.42, P=0.021\right.$; Fig. $\left.3 \mathrm{~b}\right)$ or soil organic $\mathrm{C}\left(R^{2}\right.$ $=0.70, P=0.0014$; Fig. $3 \mathrm{c}$ ) were positively correlated with the change in microbial necromass $\mathrm{C}$ under $\mathrm{N}$ addition. However, both the proportions of microbial necromass $\mathrm{C}$ to soil organic $C\left(R^{2}=0.45, P=0.029\right.$; Fig. $\left.3 \mathrm{~d}\right)$ and their concentrations relative to soil dry mass $\left(R^{2}=0.64, P=\right.$ 0.0019; Fig. 3e) were negatively correlated with those of microbial biomass $C$. The concentration of microbial necromass $\mathrm{C}$ was positively related to that of soil organic $\mathrm{C}\left(R^{2}=0.88, P<0.0001\right.$; Fig. $\left.3 f\right)$.

Effects of $\mathrm{N}$ addition under different application rates and experimental periods

The influence of $\mathrm{N}$ addition on total microbial $(P=0.77$; Fig. 4a), fungal ( $P=0.74$; Fig. $4 \mathrm{~b})$, or bacterial $(P=0.84$;
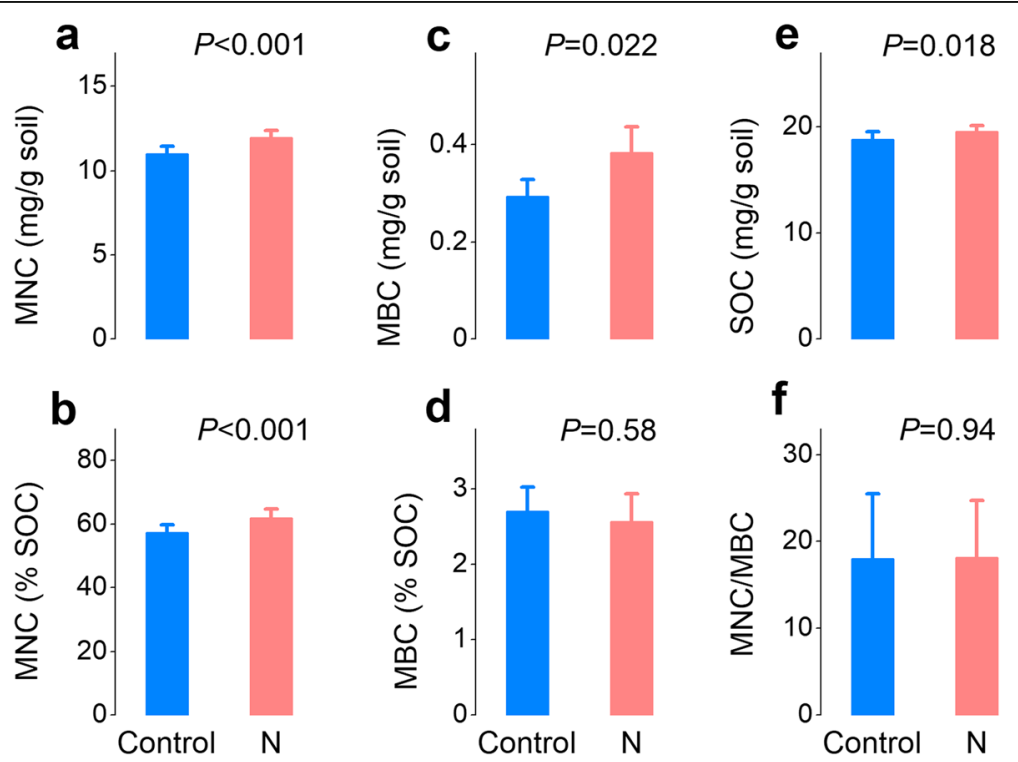

Fig. 1 Average concentrations of $\mathbf{a}$, b microbial necromass $C(M N C)$ and $\mathbf{c}$, $\mathbf{d}$ biomass $C(M B C)$ at control and $N$ addition plots. e Average concentrations of soil organic C (SOC) at control and $\mathrm{N}$ addition plots. $\mathbf{f}$ Average ratios of microbial necromass $\mathrm{C}$ to microbial biomass $\mathrm{C}$ at control and $\mathrm{N}$ addition plots. The above panels show the values presented on the basis of soil dry mass (mg/g soil), and the below panels show the values presented as percentages of soil organic C (\% SOC). Error bars represent the standard errors. The MBC values were analyzed by the chloroform fumigation extraction method. The data in panel $\mathbf{f}$ were collected only from cropland sites, at which the MBC concentrations were determined 

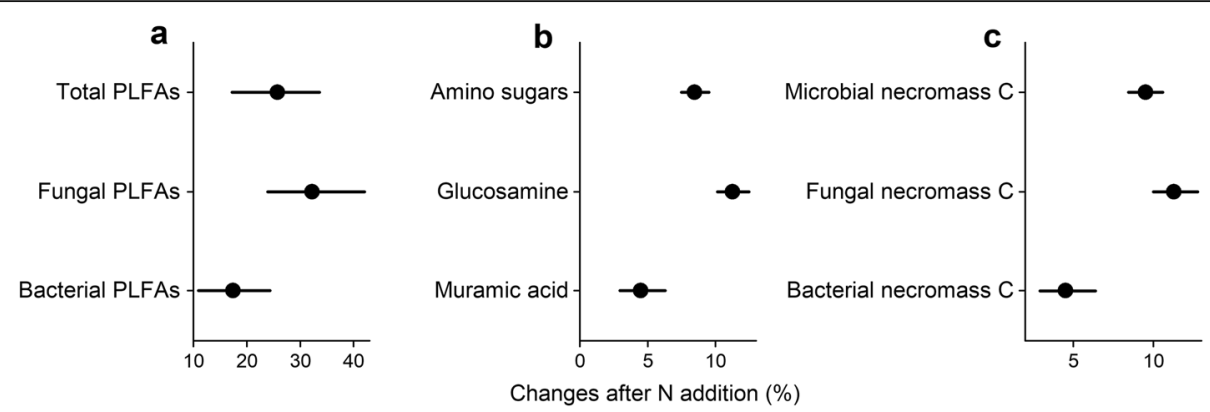

Fig. 2 Percent changes in a phospholipid fatty acids (PLFAs), b amino sugars, and c microbial necromass carbon (C) after nitrogen (N) addition. The upper values show the total PLFAs, amino sugars, and microbial necromass $C$, and the middle and lower values show the fungal and bacterial values separately. Glucosamine and muramic acid are biomarkers for fungal and bacterial necromass C, respectively. Error bars represent the 95\% bootstrap confidence intervals that were calculated by weighted effect sizes. The responses of these variables to $\mathrm{N}$ addition are considered significant $(P<0.05)$ if the $95 \%$ bootstrap confidence intervals do not overlap with zero. All these variables were collected at the control and $\mathrm{N}$ addition plots at the 11 sites at which microbial necromass $\mathrm{C}$ data were obtained

Fig. 4c) necromass $C$ or amino sugars (all $P>0.05$; Figs. S6a-c) did not significantly differ among different $\mathrm{N}$ application rates. However, the stimulation of $\mathrm{N}$ addition was greater when the experimental period was longer than 1 year either for microbial necromass $C$ (all $P<$ 0.05; Fig. $4 \mathrm{~d}-\mathrm{f}$ ) or for amino sugars (all $P<0.05$; Figs. S6d-f).

Moreover, the influence of $\mathrm{N}$ addition on microbial biomass $\mathrm{C}$ and total, fungal and bacterial PLFAs was significantly greater when the $\mathrm{N}$ dose greater than $200 \mathrm{~kg}$ $\mathrm{N} / \mathrm{ha} / \mathrm{yr}$ (all $P<0.05$; Fig. $5 \mathrm{a}-\mathrm{d}$ ) and the experimental period was longer than 10 years (all $P<0.05$; Fig. $5 \mathrm{e}-\mathrm{h}$ ).

\section{Effects of $\mathrm{N}$ addition under different $\mathrm{N}$ forms and experimental conditions}

Although the accumulation of total microbial, fungal, and bacterial necromass $\mathrm{C}$ was significantly stimulated under different forms of $\mathrm{N}$ addition, the magnitude of the stimulation was greater after urea addition than inorganic $\mathrm{N}$ (nitrate and ammonium) inputs (Fig. 6a-c). Moreover, the influence of $\mathrm{N}$ addition on total microbial $(P=0.002$; Fig. $6 \mathrm{~d})$, fungal $(P=0.001$; Fig. $6 \mathrm{e})$, and bacterial $(P=0.001$; Fig. $6 \mathrm{f})$ necromass $C$ was greater under the field conditions than under the laboratory incubation condition.

\section{Proportions of microbial necromass $\mathrm{C}$ in soil organic $\mathrm{C}$ without $\mathrm{N}$ addition}

The concentration of amino sugars ranged from 0.16 to $5.30 \mathrm{mg} / \mathrm{g}$ soil, and the proportions of microbial necromass $C$ in soil organic $C$ ranged from 11.07 to $91.20 \%$ across the study sites (Table 1 ). The total microbial, fungal, and bacterial necromass $\mathrm{C}$ accounted for averages of $49.5 \%, 35.2 \%$, and $14.5 \%$, respectively, of soil organic C without $\mathrm{N}$ addition across the 11 sites, with higher values observed in croplands than in forests (Table 2).

\section{Biogeochemical controls over soil microbial necromass C} without $\mathrm{N}$ addition

The RDA analysis results showed that soil $\mathrm{N}$ concentration was the main determinant for both total microbial and fungal necromass $\mathrm{C}$ (Fig. 7a). The PLS analysis results indicated that fungal necromass $\mathrm{C}$ was also strongly determined by elevation, whereas bacterial necromass $C$ varied significantly along with latitude (Fig. $7 \mathrm{~b}$ ). Nevertheless, the soil $\mathrm{pH}$ and $\mathrm{C} / \mathrm{N}$ ratio had negative effects on both fungal and bacterial necromass C (Table S8).

\section{Discussion}

Previous meta-analysis studies have shown that $\mathrm{N}$ addition increases $\mathrm{C}$ input to soils (LeBauer and Treseder 2008) but decreases $C$ loss from soils due to lowered microbial activity (Liu and Greaver 2010), resulting in a potential increase in soil $\mathrm{C}$ sequestration after $\mathrm{N}$ addition (Table S9; Cusack et al. 2010; Lu et al. 2011). However, this increase in soil organic $C$ that originates from microbial residues has not been differentiated without identifying the prominent role of microbial biomass turnover. Our synthesis showed that the stimulated accumulation of microbial necromass $\mathrm{C}$ may be one of the pathways for the observed increase in soil organic $\mathrm{C}$ under $\mathrm{N}$ addition across China's terrestrial ecosystems.

Inconsistent with the prevailing synthesis of decreased soil microbial biomass under $\mathrm{N}$ addition in terrestrial ecosystems worldwide (Table S9; Zhang et al. 2018), we found that the averaged microbial biomass was considerably increased after $\mathrm{N}$ addition at the studied sites and that both chloroform fumigation and PLFA analyses yielded consistent results, regardless of the $\mathrm{N}$ dose and duration (Fig. 5). This inconsistency could be attributed to several reasons. First, the data included in this study was limited, and most of the data were collected from croplands (Table S6), which may show divergent patterns in microbial biomass $\mathrm{C}$ in response to $\mathrm{N}$ addition 


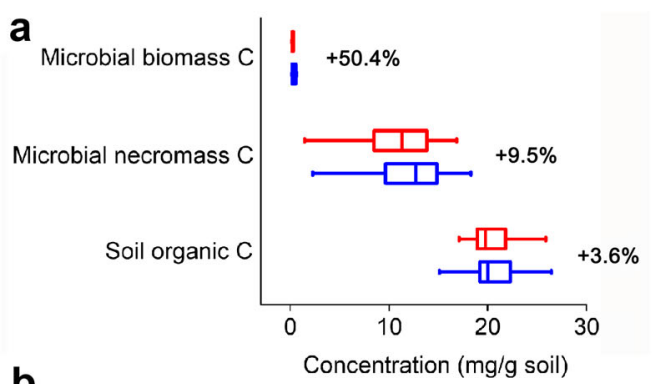

b
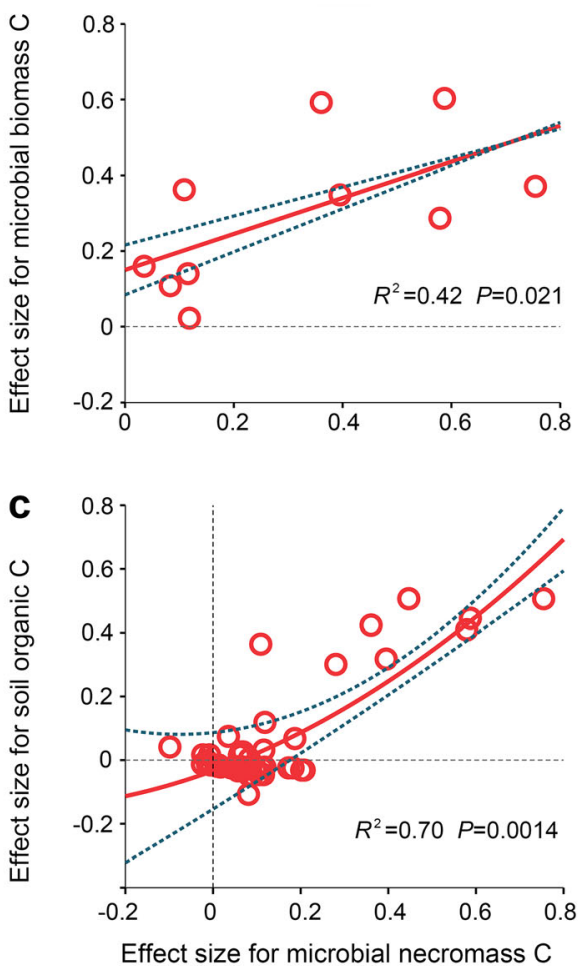

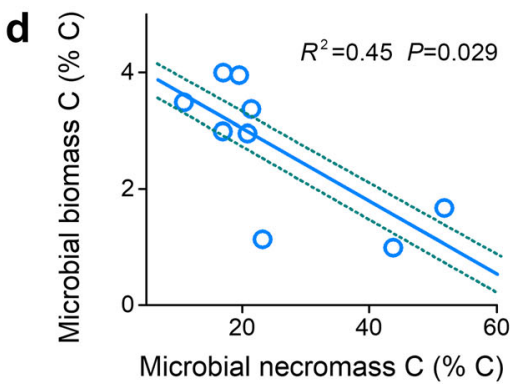

e
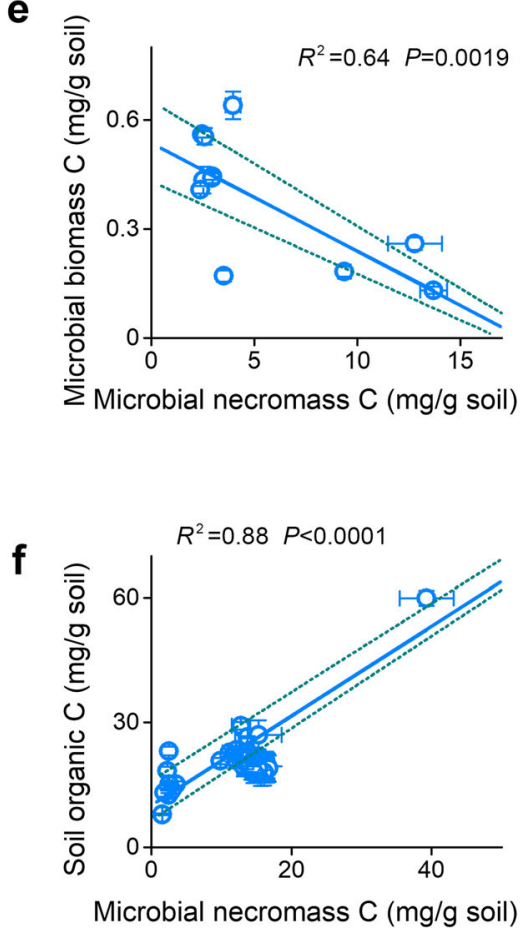

Fig. 3 a Average concentrations of microbial biomass $C$, microbial necromass $C$, and soil organic $C$ at control (red) and $\mathrm{N}$ addition (blue) plots across the studied sites. The box plots show the median and 25th and 75th percentiles. The values show percent changes in microbial biomass $\mathrm{C}$, microbial necromass $\mathrm{C}$, and soil organic $\mathrm{C}$ under $\mathrm{N}$ addition. All these variables were collected at the control and $\mathrm{N}$ addition plots at the 11 sites at which microbial necromass $C$ data were obtained. Microbial biomass $C$ values are presented on the basis of chloroform fumigation extraction analysis. $\mathbf{b}, \mathbf{c}$ The effect sizes of $\mathrm{N}$ addition on microbial necromass $\mathrm{C}$ plotted against the effect sizes on microbial biomass $\mathrm{C}$ and soil organic $\mathbf{C}$, respectively. $\mathbf{d}$ Proportions of microbial necromass $C$ in soil organic $C$ versus those of microbial biomass $C$ in soil organic $C$. e, $\mathbf{f}$ The concentrations of microbial necromass $C$ versus those of microbial biomass $C$ and soil organic $C$, respectively. All data shown in panels $\mathbf{d}-\mathbf{f}$ were collected at control plots, and error bars represent the standard errors. The dotted lines show the $95 \%$ confidence intervals, and the adjusted $R^{2}$ and $P$ values are shown in all panels except panel a

compared with other ecosystems (i.e., grassland; Geisseler et al. 2016). Moreover, the influence of $\mathrm{N}$ addition may vary between regions and ecosystems. Deng et al. (2018) collected data from 127 sites and found that soil microbial biomass $\mathrm{C}$ was increased by an average of $8.8 \%$ across China' terrestrial ecosystems, regardless of the $\mathrm{N}$ form and application rate. In addition, the evidence from $454 \mathrm{~N}$ addition experiments found that elevated $\mathrm{N}$ had positive effects on the soil microbial biomass when the $\mathrm{N}$ application rate was lower than $100 \mathrm{~kg} \mathrm{~N} / \mathrm{ha} / \mathrm{yr}$, while this effect became negative under high $\mathrm{N}$ input (Zhou et al. 2017). It is noteworthy that the proportions of microbial biomass $\mathrm{C}$ in soil organic $\mathrm{C}$ did not differ $(P=0.58$; Fig. 1d) after $\mathrm{N}$ addition, which significantly increased the soil organic $C$ concentration $(P=0.018$; Fig. $1 \mathrm{e})$ and diluted the increase in microbial biomass $\mathrm{C}$.

Although the stimulation of soil microbial biomass under elevated $\mathrm{N}$ occurred in parallel with the increase in microbial necromass $\mathrm{C}$ after $\mathrm{N}$ addition $\left(R^{2}=0.42, P\right.$ $=0.021$; Fig. $3 \mathrm{~b}$ ), higher accumulation of microbial necromass $\mathrm{C}$ was not found at sites with higher 
Microbial necromass $\mathrm{C}$
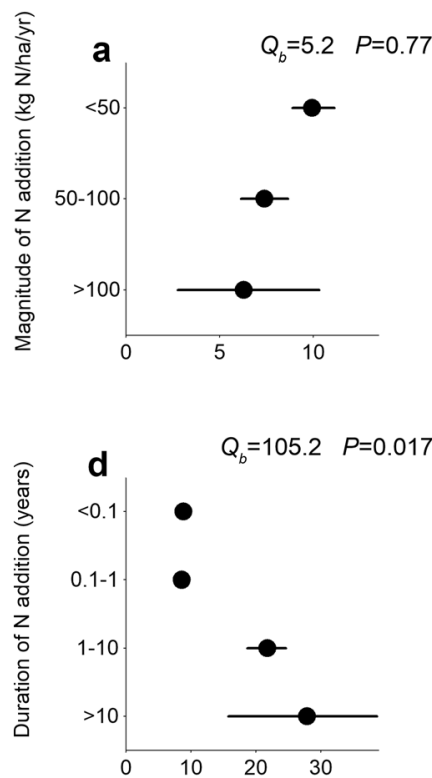

Fungal necromass $\mathrm{C}$

b

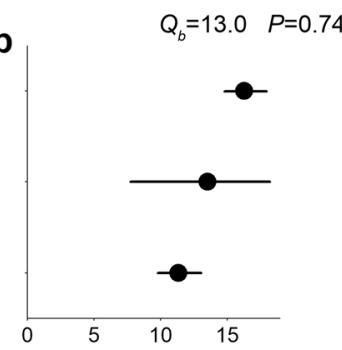

e

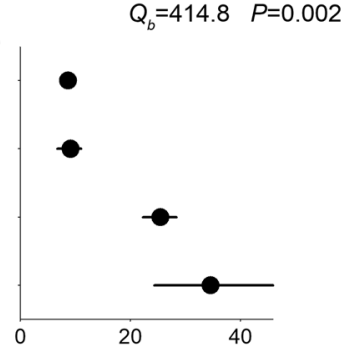

Bacterial necromass $\mathrm{C}$
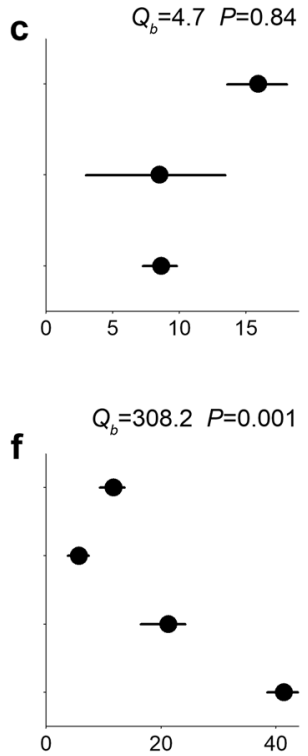

Changes after $\mathrm{N}$ addition (\%)

Fig. 4 Percent changes in microbial necromass $C$ under different magnitudes (upper) and durations (lower) of $N$ addition. a, $\mathbf{d}$ Total microbial necromass $\mathbf{C}$, b, e fungal necromass $\mathbf{C}$, and $\mathbf{c}$, $\mathbf{f}$ bacterial necromass $\mathbf{C}$. Error bars represent the $95 \%$ bootstrap confidence intervals that were calculated by weighted effect sizes. The responses of these variables to different magnitudes and durations of $\mathrm{N}$ addition are considered significant $(P<0.05)$ if the $95 \%$ bootstrap confidence intervals do not overlap with zero. The between-group heterogeneities $\left(Q_{b}\right)$ and the probabilities $(P)$ of the effects of $\mathrm{N}$ addition on microbial necromass $\mathrm{C}$ across different magnitudes and durations are shown in each panel
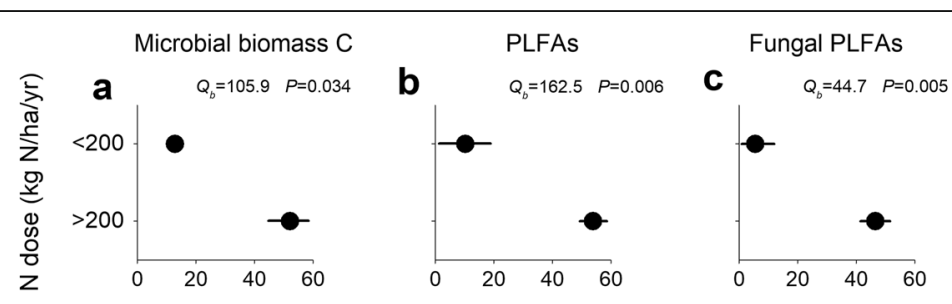

\section{Bacterial PLFAs}

d
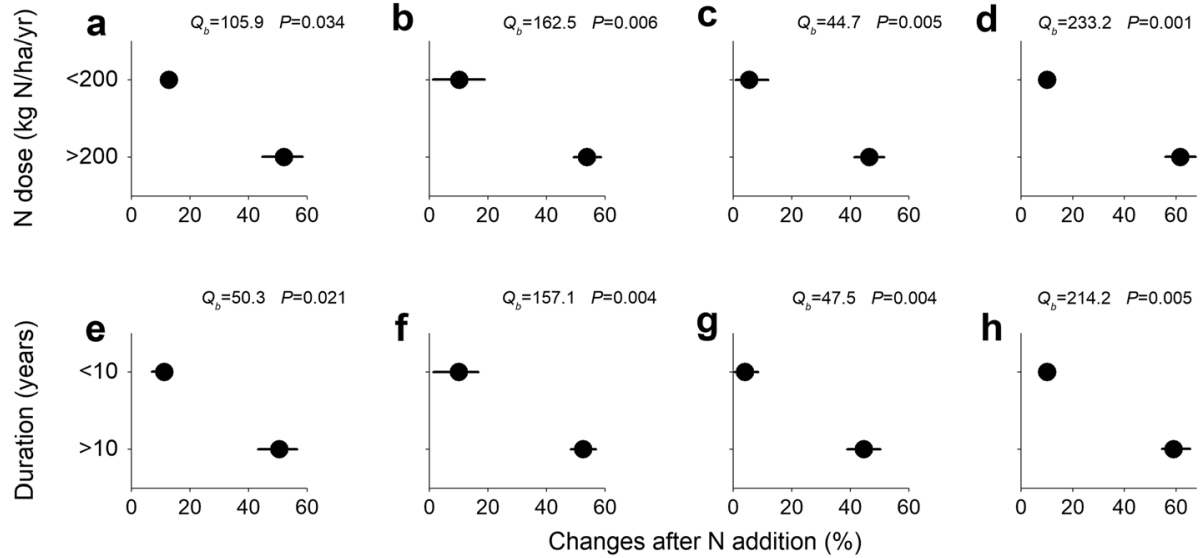

Fig. 5 Percent changes in microbial biomass under different magnitudes (upper) and durations (lower) of $\mathrm{N}$ addition. a, e Microbial biomass $\mathrm{C}$ based on chloroform fumigation extraction analysis, $\mathbf{b}, \mathbf{f}$ total phospholipid fatty acids (PLFAs), $\mathbf{c}, \mathbf{g}$ fungal PLFAs, and $\mathbf{d}, \mathbf{h}$ bacterial PLFAs. Error bars represent the $95 \%$ bootstrap confidence intervals that were calculated by weighted effect sizes. The responses of these variables to different magnitudes and durations of $\mathrm{N}$ addition are considered significant $(P<0.05)$ if the $95 \%$ bootstrap confidence intervals do not overlap with zero. The between-group heterogeneities $\left(Q_{b}\right)$ and the probabilities $(P)$ of the effects of $N$ addition on microbial biomass across different magnitudes and durations are shown in each panel 

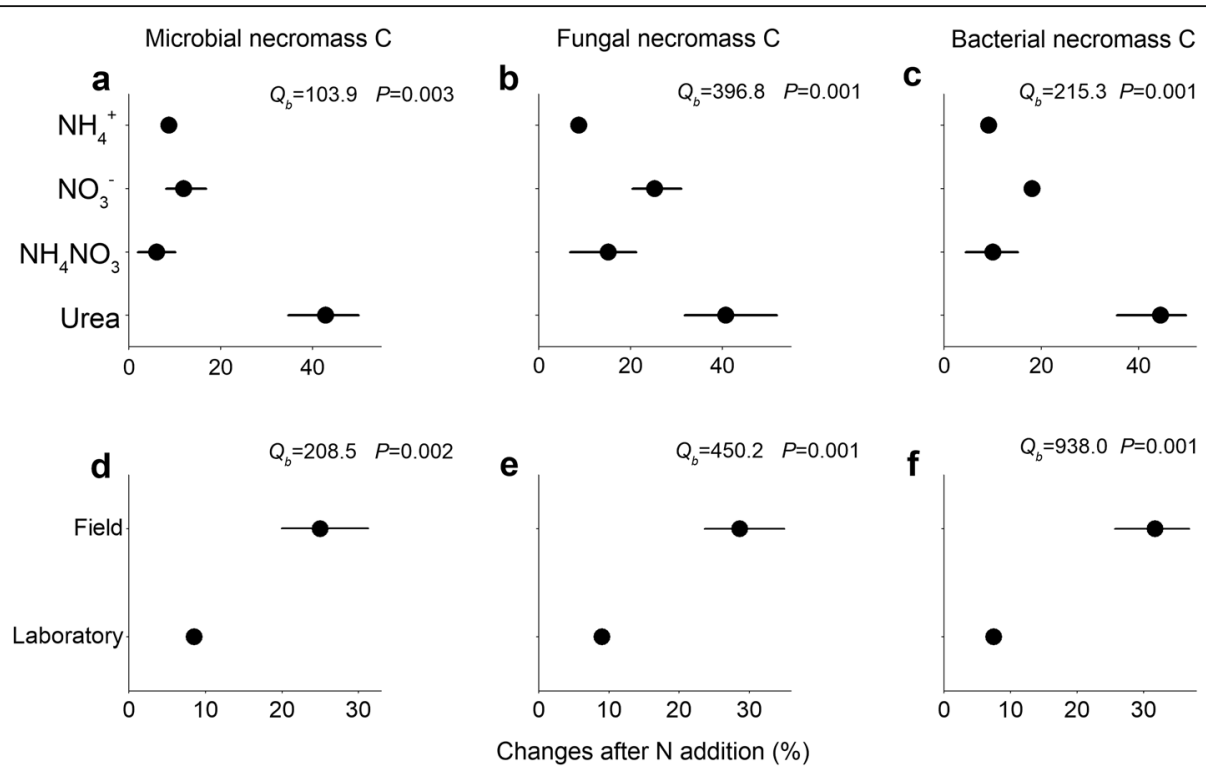

Fig. 6 Percent changes in microbial necromass $C$ under different $N$ forms (upper) and experimental conditions (lower). a, d Total microbial necromass $\mathbf{C}, \mathbf{b}$, e fungal necromass $\mathbf{C}$, and $\mathbf{c}$, $\mathbf{f}$ bacterial necromass $\mathbf{C}$. Error bars represent the $95 \%$ bootstrap confidence intervals that were calculated by weighted effect sizes. The responses of these variables to different $\mathrm{N}$ forms and experimental conditions are considered significant $(P<0.05)$ if the $95 \%$ bootstrap confidence intervals do not overlap with zero. The between-group heterogeneities $\left(Q_{b}\right)$ and the probabilities $(P)$ of the effects of $\mathrm{N}$ addition on microbial necromass $\mathrm{C}$ across different $\mathrm{N}$ forms and experimental conditions are shown in each panel

microbial biomass (Fig. 3d, e). Alternatively, the accumulation of microbial residues was strongly related to the soil $\mathrm{N}$ concentration under natural conditions without $\mathrm{N}$ addition (Fig. 7), suggesting that soil nutrients exert significant control over microbial necromass accumulation in these ecosystems. An important reason is that labile substrates with more intrinsic $\mathrm{N}$ are assimilated easily by microorganisms with high $\mathrm{C}$ use efficiency, resulting in more microbial residues contributing to soil organic $\mathrm{C}$ after biomass turnover (Cotrufo et al. 2013; Liang et al. 2017). Moreover, elevated $\mathrm{N}$ availability after external N input further alleviated microbial $\mathrm{N}$ limitation in most terrestrial ecosystems (Cheng et al. 2020). Studies have found that the activities of $\mathrm{N}$-acquisition enzymes (such as $\beta-1,4-N$-acetyl-glucosaminidase) are increased dramatically after external $\mathrm{N}$ input in forests and grasslands (Gutknecht et al. 2010; Dong et al. 2015), suggesting that the $\mathrm{N}$ mining is still stimulated under $\mathrm{N}$ addition in many terrestrial ecosystems (Jian et al. 2016). Therefore, the accumulation of microbial necromass $C$ is strongly controlled by soil $\mathrm{N}$ availability under increasing $\mathrm{N}$ application rates and experimental periods.

The long-term persistence of microbial necromass C in soils depends on the occlusion of microbial residues in aggregates and on adsorption on mineral surfaces in many undisturbed ecosystems (Dungait et al. 2012; Hemingway et al. 2019). A previous study conducted in a temperate forest found that the increased soil organic $\mathrm{C}$ under elevated $\mathrm{N}$ was occluded in mineral soil particles after 20 years of $\mathrm{N}$ addition (Zak et al. 2017), while another recent study suggested that the increased soil $C$ was preferentially sequestered in particulate fractions in a subtropical forest (Chen et al. 2020). Moreover, studies conducted at croplands with different soil texture also found that both particulate and mineralassociated soil organic $\mathrm{C}$ were increased profoundly after long-term (17 years) $\mathrm{N}$ addition (He et al. 2015). These results suggest that elevated $\mathrm{N}$ not only increases mineral-associated soil organic $\mathrm{C}$ but also stimulates the formation of occluded organic $\mathrm{C}$ for long-term persistence, with a potential to foster greater soil $\mathrm{C}$ storage under $\mathrm{N}$ deposition in many terrestrial ecosystems. Compared with plant-derived detritus, microbial residues have fewer molecular sizes and can be occluded in microaggregates and adsorbed on mineral particles more efficiently against enzyme attack (van Lützow et al. 2006). Therefore, the stimulated accumulation of microbial necromass $\mathrm{C}$ may be an important pathway for the observed increase in soil organic $\mathrm{C}$ under elevated $\mathrm{N}$ in previous studies (Liu and Greaver 2010; Lu et al. 2011).

Recent conceptual frameworks have proposed that microbial residues after biomass turnover are a significant source of soil organic C (Cotrufo et al. 2013; Liang et al. 2017). These organic compounds in cell walls after microbial cell death, including fragments of cell envelopes and other cytosolic materials (such as proteins, lipids, and nucleic acids), are maintained in soils over long term (Bradford et al. 2013). However, more evidence is 
Table 1 Concentrations of amino sugars and microbial necromass $C$ at the study sites

\begin{tabular}{|c|c|c|c|c|c|c|c|c|c|c|c|c|}
\hline \multirow[t]{2}{*}{ Citation } & \multirow[t]{2}{*}{ Site } & \multirow[t]{2}{*}{ Ecosystem } & \multirow[t]{2}{*}{$\begin{array}{l}\text { SOC (mg/ } \\
\text { g soil) }\end{array}$} & \multicolumn{3}{|c|}{$\begin{array}{l}\text { Amino sugars } \\
\text { (mg/g soil) }\end{array}$} & \multicolumn{3}{|c|}{$\begin{array}{l}\text { Microbial necromass C } \\
\text { (mg/g soil) }\end{array}$} & \multicolumn{3}{|c|}{$\begin{array}{l}\text { Microbial necromass C } \\
\text { (\% SOC) }\end{array}$} \\
\hline & & & & Total & Glu & Mur & Total & Fungal & Bacterial & Total & Fungal & Bacteria \\
\hline Ding et al. (2009) & Gongzhuling, Jilin & Cropland & 15.60 & 1.98 & 1.06 & 0.104 & 14.23 & 9.56 & 4.67 & 91.20 & 61.27 & 29.93 \\
\hline Ding et al. (2010) & Gongzhuling, Jilin & Cropland & 15.60 & 1.98 & 1.06 & 0.104 & 12.88 & 8.21 & 4.66 & 82.54 & 52.67 & 29.88 \\
\hline Ding et al. (2011a) & $\begin{array}{l}\text { Shenyang Agricultural } \\
\text { University, Liaoning }\end{array}$ & Cropland & 10.50 & 1.05 & 0.69 & 0.073 & 8.53 & 5.26 & 3.27 & 81.25 & 50.06 & 31.19 \\
\hline Li et al. (2012) & Gongzhuling, Jilin & Cropland & 17.40 & 1.01 & 0.71 & 0.045 & 8.43 & 6.40 & 2.03 & 48.46 & 36.77 & 11.68 \\
\hline Ding et al. (2013a) & Hailun, Heilongjiang & Cropland & 27.10 & 1.73 & 1.08 & 0.056 & 12.28 & 9.76 & 2.52 & 45.32 & 36.02 & 9.30 \\
\hline Ding et al. (2013c) & Hailun, Heilongjiang & Cropland & 27.10 & 1.71 & 1.06 & 0.062 & 12.33 & 9.55 & 2.78 & 45.50 & 35.26 & 10.24 \\
\hline Li et al. (2015) & Hailun, Heilongjiang & Cropland & 6.99 & 0.18 & 0.11 & 0.010 & 1.46 & 1.01 & 0.45 & 20.88 & 14.42 & 6.46 \\
\hline Chen et al. (2018) & Taoyuan, Hunan & Cropland & 17.00 & 1.30 & 0.79 & 0.062 & 9.89 & 7.09 & 2.80 & 58.19 & 41.72 & 16.46 \\
\hline Zhang et al. (2018) & Qianyanzhou, Jiangxi & Cropland & 9.70 & 0.19 & 0.100 & 0.023 & 1.65 & 0.89 & 1.05 & 17.01 & 9.18 & 10.82 \\
\hline Li et al. (2019) & Luancheng, Hebei & Cropland & 8.76 & 0.49 & 0.31 & 0.014 & 3.46 & 2.81 & 0.65 & 39.48 & 32.09 & 7.38 \\
\hline Ning et al. (2019) & Ningxiang, Hunan & Cropland & 17.05 & 1.22 & 0.73 & 0.056 & 9.07 & 6.55 & 2.51 & 53.18 & 38.43 & 14.75 \\
\hline Luo et al. (2020) & Haibei, Qinghai & Grassland & 66.70 & 5.30 & 3.36 & 0.186 & 36.24 & 27.90 & 8.33 & 54.34 & 41.83 & 12.49 \\
\hline Ma et al. (2020) & Jianfengling, Hainan & Forest & 25.90 & 2.01 & 1.47 & 0.079 & 16.82 & 13.26 & 3.57 & 64.96 & 51.18 & 13.77 \\
\hline Cui et al. (2016) & Dinghushan, Guangdong & Forest & 42.50 & 1.88 & 1.40 & 0.079 & 15.15 & 11.61 & 3.54 & 35.64 & 27.31 & 8.32 \\
\hline Zhang et al. (2016) & Dinghushan, Guangdong & Forest & 37.77 & 1.97 & 1.37 & 0.119 & 16.19 & 10.84 & 5.35 & 42.87 & 28.69 & 14.16 \\
\hline Ma et al. (2018) & Shixi, Jiangxi & Forest & 17.16 & 0.16 & 0.14 & 0.020 & 1.90 & 1.01 & 0.89 & 11.07 & 5.89 & 5.18 \\
\hline
\end{tabular}

The values are the means of all measurements determined at the study sites. All data were collected at the control plots without $\mathrm{N}$ addition. The citations are available in Supplementary Text S1

$C$ carbon, SOC soil organic carbon, Glu glucosamine, Mur muramic acid

needed to elucidate the importance of microbial necromass $\mathrm{C}$ in soil $\mathrm{C}$ sequestration, particularly in global change scenarios. A recent synthesis suggested that $30 \%, 61.8 \%$, and $55.6 \%$ of soil organic $C$ in the upper $30 \mathrm{~cm}$ of soil layers were originated from microbial residues in forests, grasslands, and croplands, respectively, in temperate regions (Liang et al. 2019). Similarly, our previous study has indicated that microbial necromass $\mathrm{C}$ accounts for averages of $30 \%$ and $33 \%$ in $\mathrm{O}$ horizon and $0-20 \mathrm{~cm}$ mineral soils, respectively, across global forests ( $\mathrm{Ni}$ et al. 2020a). In this study, we found that total microbial necromass $\mathrm{C}$ was an average of 18 times higher than microbial biomass $\mathrm{C}$, accounting for $49.5 \%$ of soil organic $C$ in the upper $20-\mathrm{cm}$ soil layers across the studied sites in China's terrestrial ecosystems, with higher values observed in croplands (53.0\%) and lower values in forests (38.6\%, Table 2), similar to previous estimations. Although this study only assessed the changes in microbial necromass $\mathrm{C}$ under $\mathrm{N}$ addition across China's terrestrial ecosystems, all these theoretical frameworks and quantitative estimations highlight the importance of microbial residues in maintaining the long-term persistence of soil organic $\mathrm{C}$ under global change worldwide.

\section{Conclusion}

Microbial necromass $\mathrm{C}$ was a significant source of soil organic $\mathrm{C}$ formation, accounting for an average of $49.5 \%$ of total soil organic $\mathrm{C}$ at the studied sites across China's terrestrial ecosystems. Therefore, it is important to distinguish the soil organic $C$ that is originated from microbial residues under $\mathrm{N}$ deposition. This microbial pathway of soil $\mathrm{C}$ sequestration was significantly increased by $9.5 \%$ under $\mathrm{N}$ addition, with higher stimulation observed for

Table 2 Percentages of microbial necromass $C$ in soil organic $C$ in different ecosystems

\begin{tabular}{lllll}
\hline Ecosystem & $\begin{array}{l}\text { Soil organic C } \\
\text { (mg/g soil) }\end{array}$ & $\begin{array}{l}\text { Microbial necromass C } \\
\text { (\% SOC) }\end{array}$ & $\begin{array}{l}\text { Fungal necromass C } \\
\text { (\% SOC) }\end{array}$ & $\begin{array}{l}\text { Bacterial necromass C } \\
\text { (\% SOC) }\end{array}$ \\
\hline All & $22.68 \pm 3.87$ & $49.49 \pm 5.74$ & $35.17 \pm 3.90$ & $14.50 \pm 2.11$ \\
Cropland & $15.71 \pm 2.03$ & $53.00 \pm 7.26$ & $37.08 \pm 4.61$ & $16.19 \pm 2.87$ \\
Forest & $30.83 \pm 5.74$ & $38.63 \pm 11.10$ & $28.27 \pm 9.25$ & $10.36 \pm 2.18$ \\
Grassland & 66.70 & 36.24 & 27.90 & 8.33 \\
\hline
\end{tabular}

Error bars are standard errors of the mean (except in grassland). All data were collected at the control plots without $\mathrm{N}$ addition and were the average values at each site C carbon, SOC soil organic carbon 

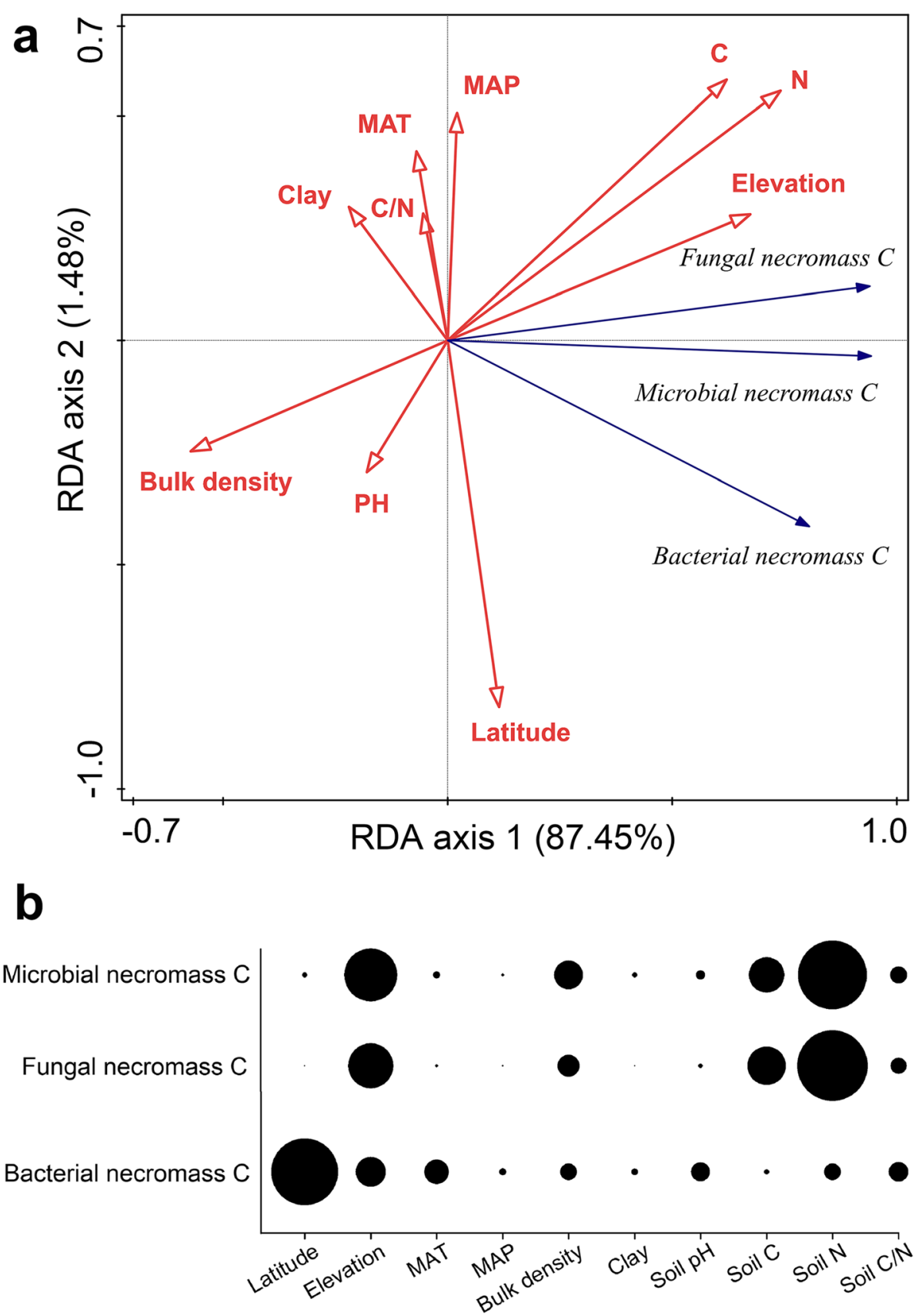

Fig. 7 a Ordination biplot of the redundancy analysis (RDA) on microbial necromass $C$ and geochemical variables. The variances explained by geochemical variables are shown on axes $1(87.45 \%)$ and $2(1.48 \%)$, respectively. The explanatory variables are indicated by different arrows: microbial necromass $C$ by blue arrows and geochemical variables by red arrows. Arrows with narrow angles $\left(<90^{\circ}\right)$ are positive correlations, and arrows in opposite directions $\left(>90^{\circ}\right)$ show negative correlations. $\mathbf{b}$ The relative importance of geochemical variables to microbial necromass $\mathbf{C}$. All variables were collected at the control plots (without $\mathrm{N}$ addition) at the 11 sites at which the microbial necromass $\mathrm{C}$ data were obtained. The circle size is proportional to the variable importance values (the importance of variance explained) based on partial least square regressions within each row. The most important variable has the largest circle, but the circle size is comparable only within a row. The adjusted $R^{2}$ values are $0.882,0.848$, and 0.746 for total microbial, fungal, and bacterial necromass $C$, respectively (all $n=118$ ). MAT, mean annual temperature; MAP, mean annual precipitation; $C$, carbon; $N$, nitrogen; $C / N$, soil carbon to nitrogen ratio

fungal than bacterial necromass $\mathrm{C}$. This increase in microbial necromass $\mathrm{C}$ was highly proportional to the increase in soil organic $\mathrm{C}$ under $\mathrm{N}$ addition, suggesting that the stimulation of microbial necromass $\mathrm{C}$ is one of the pathways for the observed increase in soil organic $\mathrm{C}$ under $\mathrm{N}$ addition in previous studies. 


\section{Supplementary information}

Supplementary information accompanies this paper at https://doi.org/10. 1186/s13717-020-00260-7.

Additional file 1. Supplementary Dataset S1. Current measurements of microbial necromass C under $\mathrm{N}$ addition. Supplementary Dataset S2. Effect sizes for microbial necromass $\mathrm{C}$ in response to $\mathrm{N}$ addition.

Additional file 2. Text S1. Supplementary notes for data compilation. Figure S1 Concentrations of amino sugar biomarkers plotted against microbial necromass C. (a) Total amino sugars versus total microbial necromass C, (b) glucosamine versus fungal necromass $C_{\text {, }}(\mathrm{c})$ muramic acid versus bacterial necromass $C$. All data were collected at the control plots without $\mathrm{N}$ addition. Pearson's $r$ and $P$ values from linear regressions are shown in each panel. Figure S2 Differences in the effect sizes of $\mathrm{N}$ addition on (a) total microbial, (b) fungal, and (c) bacterial necromass $\mathrm{C}$ before and after the data that were calculated by amino sugar biomarkers were included in our dataset. The red boxes show the data that were obtained directly from the articles $(n=13,8$, and 8 for panels $a, b$ and $c$, respectively). The blue boxes show the data that were obtained directly from the articles plus the data that were calculated by corresponding amino sugar biomarkers (all $n=118$ ). Fungal and bacterial necromass $C$ were calculated by glucosamine and muramic acid biomarkers, respectively. The individual effect sizes were used for comparison in this analysis. The significant differences were tested by Wilcoxon rank-sum test due to the unequal sample sizes. Figure S3 Differences in the influence of $\mathrm{N}$ addition on $(a, d)$ total microbial, $(b, e)$ fungal, and $(c, f)$ bacterial necromass $C$ between forest (red; $n=14$ ) and cropland (blue; $n=$ 103). The individual effect sizes (above) and percent changes (below) were used for comparison in this analysis. The sample size was only 1 for grassland, which was not included in this analysis. The significant differences were tested by Wilcoxon rank-sum test due to the unequal sample sizes. Given that percent changes were calculated by individual effect sizes (see Response Metrics), the $P$ values were the same for the differences in individual effect sizes and percent changes. Figure S4 Frequency distribution of the effect sizes for $(a-c)$ amino sugars and $(\mathrm{d}-\mathrm{f})$ microbial necromass $\mathrm{C}$ in response to $\mathrm{N}$ addition. The solid curves are Gaussian distributions fitted to the frequency data, and the vertical dotted lines are drawn at effect sizes of zero. Sample sizes and $P$ values of the normal distribution test are shown in each panel. Figure S5 Concentrations of $(\mathrm{a}-\mathrm{C})$ amino sugars and $(\mathrm{d}-\mathrm{f})$ microbial necromass $\mathrm{C}$ at control versus $\mathrm{N}$ addition plots. Error bars represent the variances of individual effect sizes calculated by means, standard deviations, and sample sizes for controls and $\mathrm{N}$ addition on both the $X$ - and $Y$-axes. The dotted blue lines show 1:1 lines. Adjusted $R^{2}$ and $P$ values from linear regressions for testing the relationships between the control and $\mathrm{N}$ addition plots are shown at the top of each panel, and sample sizes and $p$ values from Bray-Curtis analyses for comparing the differences between the control and $\mathrm{N}$ addition plots are shown at the bottom of each panel. Figure S6 Percent changes in amino sugars under different magnitudes (upper) and durations (lower) of N addition. (a, d) Total amino sugars, (b, e) glucosamine, (c, f) muramic acid. Error bars represent the $95 \%$ bootstrap confidence intervals that were calculated by weighted effect sizes. The between-group heterogeneities $\left(Q_{b}\right)$ and the probabilities $(P)$ of the effects of $N$ addition on amino sugars across different magnitudes and durations are shown in each panel. The vertical dotted lines are drawn at percent changes of zero. The responses of these variables to different magnitudes and durations of $\mathrm{N}$ addition are considered significant $(P<0.05)$ if the $95 \%$ bootstrap confidence intervals do not overlap with zero. Table S1 The study sites at which microbial necromass $C$ was measured under $N$ addition. Table S2 Soil biogeochemical properties at the study sites at which microbial necromass $\mathrm{C}$ was measured under $\mathrm{N}$ addition. Table S3 The hydrolysis conditions used to determine the concentrations of amino sugars in soils. Table S4 Total and between-group heterogeneities $(Q)$ and probabilities $(P)$ of the effects of $\mathrm{N}$ addition on amino sugar biomarkers and microbial necromass $\mathrm{C}$. Table S5 Individual effect sizes for soil microbial necromass $C$ in response to $\mathrm{N}$ addition. Table S6 Individual effect sizes for soil microbial biomass $\mathrm{C}$ in response to $\mathrm{N}$ addition. Table S7 Weighted effect sizes and percent changes in microbial necromass $C$ and biomass $C$ under $N$ addition. Table 58 Standardized coefficients of partial least square (PLS) regressions. Table S9 Estimates of changes in soil biogeochemical variables under $\mathrm{N}$ addition in meta-analyses.

\section{Abbreviations}

C: Carbon; Cl: Confidence interval; HCl: Hydrochloric acid; InE: Effect size; InEE: Weighted effect size; MAP: Mean annual precipitation; MAT: Mean annual temperature; MBC: Microbial biomass carbon; MNC: Microbial necromass carbon; N: Nitrogen; PLFAs: Phospholipid fatty acids; SOC: Soil organic carbon

\section{Acknowledgements}

This research was supported by the National Natural Science Foundation of China $(31800521,32022056,31800373$, and 31922052).

\section{Authors' contributions}

$\mathrm{XN}$ and FW conceived the idea. SL, ST, and DW compiled the literature data. YP and KY performed the statistical analyses. SL, XN, FW, and YY wrote the paper with inputs from all coauthors. The authors read and approved the final manuscript.

\section{Funding}

The National Natural Science Foundation of China (31800521, 32022056 , 31800373, and 31922052)

\section{Availability of data and materials}

The data presented in this paper are available in Supplementary datasets S1S2.

Ethics approval and consent to participate

Not applicable.

\section{Consent for publication}

Not applicable.

\section{Competing interests}

The authors declare that they have no competing interests.

\section{Author details}

${ }^{1}$ Key Laboratory for Humid Subtropical Eco-Geographical Processes of the Ministry of Education, School of Geographical Sciences, Fujian Normal University, 8 Shangshan Rd, Fuzhou 350007, Cangshan, China. ${ }^{2}$ Department of Geosciences and Natural Resource Management, University of Copenhagen, Rolighedsvej 23, DK-1958 Frederiksberg C, Denmark. ${ }^{3}$ Center for Biodiversity Dynamics in a Changing Word (BIOCHANGE), Section for Ecoinformatics and Biodiversity, Department of Biology, Aarhus University, Ny Munkegade 114, DK-8000 Aarhus C, Denmark.

Received: 28 May 2020 Accepted: 10 September 2020

Published online: 29 September 2020

\section{References}

Bradford MA, Keiser AD, Davies CA, Mersmann CA, Strickland MS (2013) Empirical evidence that soil carbon formation from plant inputs is positively related to microbial growth. Biogeochemistry 113:271-281

Chen J, Luo Y, van Groenigen KJ, Hungate BA, Cao J, Zhou X, Wang R (2018) A keystone microbial enzyme for nitrogen control of soil carbon storage. Sci Adv 4:eaaq1689

Chen J, Xiao W, Zheng C, Zhu B (2020) Nitrogen addition has contrasting effects on particulate and mineral-associated soil organic carbon in a subtropical forest. Soil Biol Biochem 142:107708

Cheng Y, Wang J, Wang J, Wang S, Chang SX, Cai Z, Zhang J, Niu S, Hu S (2020) Nitrogen deposition differentially affects soil gross nitrogen transformations in organic and mineral horizons. Earth-Sci Rev 201:103033

Cotrufo MF, Wallenstein MD, Boot CM, Denef K, Paul E (2013) The Microbial Efficiency-Matrix Stabilization (MEMS) framework integrates plant litter decomposition with soil organic matter stabilization: do labile plant inputs form stable soil organic matter? Global Change Biol 19:988-995

Craine JM, Morrow C, Fierer N (2007) Microbial nitrogen limitation increases decomposition. Ecology 88:2105-2113

Cusack DF, Torn MS, McDowell WH, Silver WL (2010) The response of heterotrophic activity and carbon cycling to nitrogen additions and warming in two tropical soils. Global Change Biol 16:2555-2572

Deng L, Peng C, Zhu G, Chen L, Liu Y, Shangguan Z (2018) Positive responses of belowground $C$ dynamics to nitrogen enrichment in China. Sci Total Environ 616-617:1035-1044

Dong WY, Zhang XY, Liu XY, Fu XL, Chen FS, Wang HM, Sun XM, Wen XF (2015) Responses of soil microbial communities and enzyme activities to nitrogen 
and phosphorus additions in Chinese fir plantations of subtropical China. Biogeosciences 12:5537-5546

Dungait JAJ, Hopkins DW, Gregory AS, Whitmore AP (2012) Soil organic matter turnover is governed by accessibility not recalcitrance. Global Change Biol 18:1781-1796

Eisenlord SD, Freedman Z, Zak DR, Xue K, He Z, Zhou J (2013) Microbial mechanisms mediating increased soil $C$ storage under elevated atmospheric N deposition. Appl Environ Microbiol 79:1191-1199

Fowler D, Coyle M, Skiba U, Sutton MA, Cape JN, Reis S, Sheppard $\amalg$, Jenkins A, Grizzetti B, Galloway JN, Vitousek P, Leach A, Bouwman AF, Butterbach-Bahl K, Dentener F, Stevenson D, Amann M, Voss M (2013) The global nitrogen cycle in the twenty-first century. Philos T R Soc B 368:20130164

Freedman ZB, Upchurch RA, Zak DR, Cline LC (2016) Anthropogenic N deposition slows decay by favoring bacterial metabolism: insights from metagenomic analyses. Front Microbiol 7:259

Geisseler D, Lazicki PA, Scow KM (2016) Mineral nitrogen input decreases microbial biomass in soils under grasslands but not annual crops. Appl Soil Ecol 106:1-10

Gutknecht JLM, Henry HAL, Balser TC (2010) Inter-annual variation in soil extracellular enzyme activity in response to simulated global change and fire disturbance. Pedobiologia 53:283-293

He YT, Zhang WJ, Xu MG, Tong XG, Sun FX, Wang JZ, Huang SM, Zhu P, He XH (2015) Long-term combined chemical and manure fertilizations increase soil organic carbon and total nitrogen in aggregate fractions at three typical cropland soils in China. Sci Total Environ 532:635-644

Hemingway JD, Rothmann DH, Grant KE, Rosengard SZ, Eglinton TI, Derry LA, Galy W (2019) Mineral protection regulates long-term global preservation of natural organic carbon. Nature 570:228-231

Hu Y, Zheng Q, Noll L, Zhang S, Wanek W (2020) Direct measurement of the in situ decomposition of microbial-derived soil organic matter. Soil Biol Biochem 141:107660

Janssens IA, Dieleman W, Luyssaert S, Subke J-A, Reichstein M, Ceulemans R, Ciais P, Dolman AJ, Grace J, Matteucci G, Papale D, Piao SL, Schulze E-D, Tang J, Law BE (2010) Reduction of forest soil respiration in response to nitrogen deposition. Nature Geosci 3:315-322

Jian S, Li J, Chen J, Wang G, Mayes MA, Dzantor KE, Hui D, Luo Y (2016) Soi extracellular enzyme activities, soil carbon and nitrogen storage under nitrogen fertilization: a meta-analysis. Soil Biol Biochem 101:32-43

Joergensen RG (2018) Amino sugars as specific indices for fungal and bacterial residues in soil. Biol Fertil Soils 54:559-568

Knorr M, Frey SD, Curtis PS (2005) Nitrogen additions and litter decomposition: a meta-analysis. Ecology 86:3252-3257

LeBauer DS, Treseder KK (2008) Nitrogen limitation of net primary productivity in terrestrial ecosystems is globally distributed. Ecology 89:371-379

Li T, Zhang H, Wang X, Cheng S, Fang H, Liu G, Yuan W (2019) Soil erosion affects variations of soil organic carbon and soil respiration along a slope in Northeast China. Ecol Process 8:28

Liang C, Amelung W, Lehmann J, Kästner M (2019) Quantitative assessment of microbial necromass contribution to soil organic matter. Global Change Biol 25:3578-3590

Liang C, Schimel JP, Jastrow JD (2017) The importance of anabolism in microbial control over soil carbon storage. Nat Microbiol 2:17105

Liu J, Wu N, Wang H, Sun J, Peng B, Jiang P, Bai E (2016) Nitrogen addition affects chemical composition of plant tissues, litter and soil organic matter. Ecology 97:1796-1806

Liu L, Greaver TL (2010) A global perspective on belowground carbon dynamics under nitrogen enrichment. Ecol Lett 13:819-828

Liu W, Jiang L, Yang S, Wang Z, Tian R, Peng Z, Chen Y, Zhang X, Kuang J, Ling N, Wang S, Liu L (2020) Critical transition of soil bacterial diversity and composition triggered by nitrogen enrichment. Ecology 101:e03053

Liu X, Zhang Y, Han W, Tang A, Shen J, Cui Z, Vitousek P, Erisman JW, Goulding K, Christie P, Fangmeier A, Zhang F (2013) Enhanced nitrogen deposition over China. Nature 494:459-462

Lu M, Yang Y, Luo Y, Fang C, Zhou X, Chen J, Yang X, Li B (2011) Responses of ecosystem nitrogen cycle to nitrogen addition: a meta-analysis. New Phytol 189:1040-1050

Moorhead DL, Sinsabaugh RL (2006) A theoretical model of litter decay and microbial interaction. Ecol Monogr 76:151-174

Ni X, Liao S, Tan S, Peng Y, Wang D, Yue K, Wu F, Yang Y (2020a) The vertical distribution and control of microbial necromass carbon in forest soils. Global Ecol Biogeogr. https://doi.org/10.1111/geb.13159
Ni X, Liao S, Tan S, Wang D, Peng Y, Yue K, Wu F, Yang Y (2020b) A quantitative assessment of amino sugars in soil profiles. Soil Biol Biochem 143:107762

Ni X, Yang W, Qi Z, Liao S, Xu Z, Tan B, Wang B, Wu Q, Fu C, You C, Wu F (2017) Simple additive simulation overestimates real influence: altered nitrogen and rainfall modulate the effect of warming on soil carbon fluxes. Global Change Biol 23:3371-3381

Ramirez KS, Craine JM, Fierer N (2012) Consistent effects of nitrogen amendments on soil microbial communities and processes across biomes. Global Change Biol 18:1918-1927

Reay DS, Dentener F, Smith P, Grace J, Feely RA (2008) Global nitrogen deposition and carbon sinks. Nature Geosci 1:430-437

Rosenberg MS, Adams DC, Gurevitch J (2000) MetaWin: Statistical Software for Meta-analysis. Sinauer Associates Inc., Sunderland, MA, USA

Song J, Wan S, Piao S, Knapp AK, Classen AT, Vicca S, Ciais P, Hovenden MJ, Leuzinger S, Beier C, Kardol P, Xia J, Liu Q, Ru J, Zhou Z, Luo Y, Guo D, Langley JA, Zscheischler J, Dukes JS, Tang J, Chen J, Hofmockel KS, Kueppers LM, Rustad L, Liu L, Smith MD, Templer PH, Thomas RQ, Norby RJ, Phillips RP. Niu S, Fatichi S, Wang Y, Shao P, Han H, Wang D, Lei L, Wang J, Li X, Zhang Q, Li X, Su F, Liu B, Yang F, Ma G, Li G, Liu Y, Liu Y, Yang Z, Zhang K, Miao Y, Hu M, Yan C, Zhang A, Zhong M, Hui Y, Li Y, Zheng M (2019) A meta-analysis of 1119 manipulative experiments on terrestrial carbon-cycling responses to global change. Nat Ecol Evol 3:1309-1320

ter Braak CJF, Šmilauer P (2012) Canoco Reference Manual and User's Guide: Software for Ordination, version 5.0. Microcomputer Power, Ithaca, USA

van Lützow M, Kögel-Knabner I, Ekschmitt K, Matzner E, Guggenberger G, Marschner B, Flessa H (2006) Stabilization of organic matter in temperate soils: mechanisms and their relevance under different soil conditions - a review. Eur J Soil Sci 57:426-445

Wang C, Liu D, Bai E (2018) Decreasing soil microbial diversity is associated with decreasing microbial biomass under nitrogen addition. Soil Biol Biochem 120:126-133

Yu G, Jia Y, He N, Zhu J, Chen Z, Wang Q, Piao S, Liu X, He H, Guo X, Wen Z, Li P, Ding G, Goulding K (2019) Stabilization of atmospheric nitrogen deposition in China over the past decade. Nat Geosci 12:424-429

Zak DR, Argiroff WA, Freedman ZB, Upchurch RA, Entwistle EM, Romanowicz KJ (2019) Anthropogenic N deposition, fungal gene expression, and an increasing soil carbon sink in the Northern Hemisphere. Ecology 100:e02804

Zak DR, Freedman ZB, Upchurch RA, Steffens M, Kögel-Knabner I (2017) Anthropogenic $\mathrm{N}$ deposition increases soil organic matter accumulation without altering its biochemical composition. Global Change Biol 23:933-944

Zak DR, Holmes WE, Burton AJ, Pregitzer KS, Talhelm AF (2008) Simulated atmospheric $\mathrm{NO}_{3}{ }^{-}$deposition increases soil organic matter by slowing decomposition. Ecol Appl 18:2016-2027

Zelles $L$ (1988) The simultaneous determination of muramic acid glucosamine in soil by high-performance liquid chromatography with precolumn fluorescence derivatization. Biol Fertil Soils 6:125-130

Zhang T, Chen HYH, Ruan H (2018) Global negative effects of nitrogen deposition on soil microbes. ISME J 12:1817-1825

Zhang X, Amelung W (1996) Gas chromatographic determination of muramic acid, glucosamine, mannosamine, and galactosamine in soils. Soil Biol Biochem 28:1201-1206

Zhou Z, Wang C, Zheng M, Jiang L, Luo Y (2017) Patterns and mechanisms of responses by soil microbial communities to nitrogen addition. Soil Biol Biochem 115:433-441

\section{Publisher's Note}

Springer Nature remains neutral with regard to jurisdictional claims in published maps and institutional affiliations. 